\title{
AGGREGATOR OTOMATIS PENCARI PRODUK DENGAN PEMBERITAHUAN MELALUI SUREL MENGGUNAKAN FUNGSI cURL
}

\author{
Raka Yusuf ${ }^{1}$, Harni Kusniyati ${ }^{2}$, Rani Eva Dewi ${ }^{3}$ \\ ${ }^{1,2,3}$ Program Studi Teknik Informatika, Fakultas Ilmu Komputer Universitas Mercu Buana \\ ngajar@ rakayusuf.com ${ }^{1}$, harni246@gmail.com ${ }^{2}$,rani_evadewi@yahoo.com ${ }^{3}$
}

\begin{abstract}
ABSTRAK
Aplikasi aggregator (pengumpul) otomatis untuk pencarian produk ini merupakan sebuah aplikasi yang dapat mempermudah pengguna dalam mencari produk yang diinginkan. Aplikasi ini merupakan sebuah pencari produk pada perdagangan elektronik yaitu kegiatan bisnis online yang melibatkan konsumen, produsen, penyedia layanan dan pedagang perantara dengan menggunakan jaringan komputer yaitu Internet. Hanya dengan menggunakan aplikasi ini, pencarian produk dapat dengan lebih mudah dilakukan. Dengan menggunakan teknik mengambil data di situs lain secara otomatis, aplikasi ini dapat mencari dan memberitahukan pengguna via surel (surat elektronik) bilamana ada produk yang dicarinya. Fungsi cURL adalah perintah untuk mentransfer data dari dan ke server melalui URL dengan berbagai protokol dengan menggunakan teknik penguraian kalimat yang membagi serangkaian masukan. Aplikasi dibangun menggunakan metodologi Waterfall. Dengan aplikasi ini, pengguna dapat mencari berbagai macam produk tanpa harus membuka banyak situs perdagangan dan terhubung ke Internet selama 24 jam, cukup mengakses aplikasi ini dan aplikasi inilah yang akan melakukannya. Dengan aplikasi ini pula, pengguna juga tidak perlu lagi untuk mencari produk di berbagai situs perdagangan secara satu per satu.
\end{abstract}

Kata Kunci: Agregator, Pencari Produk,Fungsi cURL, Email Pemberitahuan

\section{PENDAHULUAN}

Sudah sejak lama manusia menggunakan Internet. Kini banyak sekali pengguna yang menggunakan layanan Internet untuk memenuhi kebutuhannya dalam mencari produk yang diinginkan dan menjadikannya sarana belanja online. Biasanya untuk pemenuhan kebutuhan dalam mencari produk, pengguna terbentur dengan berbagai macam aktivitas lain yang cukup menyita waktu. Oleh karena itu, pengguna tidak bisa mencari dalam intensitas waktu yang sering di satu tempat belanja online saja. Karenanya, banyak bermunculan situs-situs Internet yang menjadi wadah dalam pemenuhan kebutuhan ini sehingga situs jual beli menjadi laris manis di pasaran dalam dunia maya dan digandrungi para pecinta setianya, terutama bagi yang mencari barang-barang bekas. Beberapa situs jual beli yang cukup dikenal pengguna Internet contohnya ialah Toko Bagus dan Berniaga yang sekarang telah bergabung dengan OLX, serta Forum Jual Beli Kaskus (fjb.kaskus.co.id), dan masih banyak situs jual beli lainnya.

Akan tetapi, biasanya produk yang diinginkan belum tentu ada atau bahkan harga yang dicantumkan tidak sesuai dengan dana yang dimiliki, sehingga harus mencari ke berbagai situs jual beli dengan harapan produk yang diinginkan dan sesuai kriteria langsung didapatkan. Namun, terkadang produk yang ada di situs tersebut tidak sesuai dengan harapan. Kalaupun ada produk yang sesuai dengan kriteria dan keuangan yang dimiliki, bukan hal yang tidak mungkin produk yang diinginkan sudah dibeli oleh orang lain karena kita terlambat melihatnya yang disebabkan kesibukan kita yang lain. Itu sebabnya pencarian ini bisa menyita waktu yang kita miliki dan pastinya akan dilakukan berulangulang hingga produk yang dicari dan sesuai kriteria dapat ditemukan.

Oleh karena itu, pada penelitian ini telah dipikirkan bagaimana membuat aplikasi aggregator yang nantinya akan membantu para pengguna dan bagaimana aplikasi ini dapat mencari produk yang diinginkan pengguna dan memberitahukannya kepada pengguna melalui surel (surat elektronik) bila telah ditemukan.Surat elektronik pemberitahuan yang dikirimkan ke pengguna aplikasi ini berisi URL (Uniform Resource Locator), yaitu rangkaian karakter menurut suatu format standar tertentu yang digunakan untuk menunjukkan alamat suatu sumber seperti dokumen dan gambar di Internet. URL tersebut akan memberikan informasi mengenai di situs mana tempat produk yang diinginkan pengguna berada. Surat elektronik pemberitahuan ini nantinya akan dikirimkan ke alamat surat elektronik pengguna yang sebelumya sudah melakukan registrasi terlebih dahulu. Selanjutnya pengguna bisa melihat keseluruhan dari produk tersebut dan memilah berdasarkan URL yang sudah dikirim ke alamat surat elektronik pengguna. 


\section{LANDASAN TEORI}

\subsection{Perdagangan Elektronik}

Menurut Keller [1], pemasaran adalah berhubungan tentang mengidentifikasi dan memenuhi kebutuhan manusia dan masyarakat. Salah satu definisi pemasaran terpendek adalah memenuhi kebutuhan secara menguntungkan. Asosiasi pemasaran Amerika menawarkan definisi yang lebih formal berikut: pemasaran adalah satu fungsi organisasi dan seperangkat proses untuk menciptakan, mengkomunikasikan, memberikan, dan menyerahkan nilai kepada pelanggan dan mengelola hubungan pelanggan dengan cara yang menguntungkan organisasi dan para pemilik sahamnya.

Perdagangan elektronik (electronic commerce) atau yang disingkat dengan e-Commerce adalah kegiatan-kegiatan bisnis yang menyangkut konsumen, manufaktur, penyedia layanan dan pedagang perantara dengan menggunakan jaringan-jaringan komputer yaitu Internet [2]. Contoh situs web yang menyediakan perdagangan elektronik ialah Amazon, eBay, Toko Bagus, Berniaga, dan lain-lain.

\subsection{Surat elektronik}

Surat elektronik (surel) atau dalam bahasa inggris disebut email yang merupakan singkatan dari electronicmail pada dasarnya sama dengan data yang dikirimkan melalui media Internet. Mayoritas lalu lintas data di Internet saat ini dipenuhi oleh surat elektronik dari suatu komputer ke komputer lainnya [3].

Surat elektronik pemberitahuan (email notification) adalah sebuah pemberitahuan laporan (report) yang berisi data apa saja melalui surat elektronik. Surat elektronik pemberitahuan merupakan layanan berbasis Internet yang fungsinya memudahkan kinerja pengguna. Biasanya surat elektronik pemberitahuan diperuntukkan untuk pengguna yang sibuk atau tidak memiliki waktu yang lebih. Surat elektronik pemberitahuan dipercaya karena fungsionalitasnya yang menghemat waktu dan biaya.

\subsection{PHP}

PHP atau singkatan dari PHP Hypertext Prepocessor adalah salah satu bahasa pemrograman kode terbuka (open source) yang cocok untuk mengembangkan Web. PHP dikenal sebagai sebuah bahasa scripting yang menyatu dengan tag-tag HTML yang dieksekusi di server dan digunakan untuk membuat halaman Web.

PHP diciptakan untuk mempermudah pengembang web dalam menulis halaman web dinamis dengan cepat, bahkan lebih dari itu kita dapat mengeskplorasi hal-hal yang luar biasa dengan PHP. Sehingga dengan demikian PHP sangat cocok untuk/bagi para pemula, menengah maupun ahli sekalipun [4].

\section{4. cURL}

cURL yaitu client URL, dikembangkan oleh Daniel Stanberg pada tahun 1998. cURL adalah baris perintah untuk mentransfer data dari dan ke server menggunakan sintaks URL melalui bermacam-macam protocol seperti: FTP, HTTP, HTTPS, TELNET, dan sebagainya. Agar cURL dapat digunakan dalam bahasa pemrograman PHP, kita harus menginstal ekstensi libcURL. libcURL adalah libraryportable yang menyediakan antar-muka untuk berbagai bahasa pemrograman seperti: PHP, perl, python, dan sebagainya.

cURL bisa digunakan setelah diaktifkan, dengan cara masuk ke file php.ini yang berada di xampp. Cari baris ; extension=PHP_CURL.dll, lalu hapus tanda titik koma (;) yang ada di baris tersebut. Setelah itu pastikan cURL sudah aktif dengan mengetikkan perintah berikut:

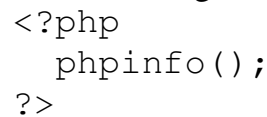

\subsection{MySQL}

MySQL adalah salah satu perangkat lunak sistem manajemen basis data (database) SQL atau sering disebut dengan DBMS (database Management System). MySQL merupakan basis data yang bersifat client server, dimana data diletakkan di server yang bisa diakses melalui komputer client. Pengaksesan dapat dilakukan apabila komputer telah terhubung dengan server. Berbeda dengan database desktop, dimana segala pemrosesan data harus dilakukan pada komputer yang bersangkutan.

\subsection{Cron Job}

Cron job adalah fasilitas yang disediakan oleh panel kontrol dari perusahaan hosting web. Cron Job akan menjalankan tugas sesuai dengan pengaturan waktu yang ditentukan. Penjadwalan yang digunakan dalam suatu aplikasi bisa diatur sesuai dengan keinginan dari pengguna. Waktunya pun bisa disesuaikan dengan kebutuhan dari sistem yang dibuat.

\subsection{Metodologi Rekayasa Perangkat Lunak}

Pemodelan dalam perangkat lunak merupakan suatu yang harus dikerjakan sebagai bagian dari rekayasa perangkat lunak itu sendiri dan akan mempengaruhi pekerjaan-pekerjaan dalam rekayasa perangkat lunak tersebut. Pemodelan yang digunakan dalam penelitian ini ialah model Waterfall.

Model Waterfall ini merupakan pendekatan terhadap perkembangan perangkat lunak yang sistematik dan sekuensial yang dimulai pada tingkat dan kemajuan sistem pada seluruh analisis, desain, kode, pengujian, dan pemeliharaan. Berikut rangkaian aktifitas proses dalam model Waterfall (Pressman, 2002): 
1. Tahap Rekayasa Sistem

2. Tahap Analisis

3. Tahap Perancangan

4. Tahap Pemrograman

5. Tahap Pengujian

\section{ANALISIS DAN PERANCANGAN SISTEM}

\subsection{Analisis Masalah}

Sebagai pengguna Internet yang sering melakukan kegiatan pemenuhan kebutuhan secara daring (online), terkadang dalam mencari produk yang diinginkan tidak selalu sesuai dengan kenyataan. Dalam pemenuhan kebutuhan ini biasanya membutuhkan waktu yang tidak sebentar, sehingga jika pengguna membutuhkan produk saat itu juga, alat elektronik pengguna diharuskan terhubung dengan Internet selama 24 jam. Bukan hanya waktu yang terbuang, tetapi juga biaya yang dikeluarkan dalam bentuk kuota Intenet. Banyaknya situs jual beli saat ini, terkadang malah membuat pengguna Internet kebingungan dalam memilih situs jual beli yang akan dikunjungi. Terlebih lagi mencari satu per satu produk yang dicari pada setiap situs jual beli. Belum lagi, jika telah menemukan produk yang dicari, akan tetapi tidak sesuai dengan kisaran harga yang dimiliki. Terkadang produk yang dicari sudah sesuai dengan kriteria dan kisaran harga, akan tetapi produk yang dicari telah terjual.

Untuk menghindari kondisi-kondisi produk yang dicari tidak sesuai dengan apa yang diharapkan. Terdapat beberapa cara atau alternatif yang dapat digunakan, tentunya dengan mempertimbangkan beberapa kelebihan dan kekurangannya, yaitu:

1. Terkoneksi ke Internet 24 jam setiap harinya. Kelebihan dari alternatif ini adalah produk yang dicari pengguna bisa didapatkan dengan kurun waktu yang singkat, sehingga dalam pemenuhan kebutuhan pengguna bisa terpuaskan dengan cepat. Kekurangan lainnya adalah produk elektronik yang digunakan untuk mencari produk akan mengalami ketidakstabilan, bisa dikarenakan kepanasan, bisa juga dikarenakan harus terhubung ke listrik sampai produk ditemukan. Terdapat satu lagi kekurangan yaitu akan menghabiskan kuota internet yang berujung kembali ke permasalahan biaya.

2. Membuat berkas (thread) tentang produk yang dicari. Kelebihannya adalah banyak pengguna Internet lainnya yang mengunjungi atau bahkan mengisi komentar di dalam berkasdengan artian banyak pengguna Internet lainnya menawarkan produk yang dicari, sehingga mudah saja dalam mendapatkan produk yang dicari, hanya dengan memilah-milah beberapa produk yang ditawarkan pengguna Internet lainnya. Kekurangan yang perlu diwaspadai adalah produk yang ditawarkan oleh pengguna lainnya, belum tentu sesuai dengan apa yang dideskripsikan dalam berkastersebut, sehingga bisa saja itu hoax (palsu). Oleh karena itu, tidak bisa asal dalam memilih produk yang ditawarkan.

3. Membuat aplikasi aggregator pencarian produk secara otomatis dengan fungsi pemberitahuan surat elektronik menggunakan fungsi cURL. Kelebihannya adalah pengguna dapat dengan mudahnya mencari produk yang sesuai dengan kriteria dan biaya yang dimiliki, sehingga tidak perlu lagi kesana kesini mencari produk. Kelebihan lainnya pengguna tidak diharuskan terkoneksi ke internet selama 24 jam. Selain itu, pengguna tidak menghabiskan banyak kuota Internet. Kekurangannya adalah tidaklah mudah dalam pembuatan aplikasi ini. Oleh karena itu, pembuatan aplikasi ini cukup menyita waktu, biaya dan hal lainnya.

Dari pemaparan lengkap mengenai kelebihan dan kekurangan ketiga alternatif tersebut, sehingga dapat disimpulkan pilihan alternatif yang terbaik dan efektif adalah dengan membuat aplikasi pencarian produk secara otomatis dengan fungsi pemberitahuan surat elektronik menggunakan fungsi cURL. Alasan membuat aplikasi pencarian produk secara otomatis dengan fungsi pemberitahuan surat elektronik menggunakan fungsi cURL ini dipilih karena aplikasi tersebut memiliki beberapa kelebihan dibandingkan dengan kedua alternatif lainnya, yaitu:

1. Dengan aplikasi aggregator pencarian produk secara otomatis dengan fungsi pemberitahuan surat elektronik menggunakan fungsi cURL pengguna tidak perlu terkoneksi ke Internet selama 24 jam. Pengguna hanya cukup dengan memeriksa pesan surat elektronik sesuai dengan waktu yang ditentukan sistem.

2. Dengan aplikasi ini pengguna tidak menghabiskan banyak kuota Internet untuk mencari produk yang diinginkan, sehingga pengguna tidak perlu mengeluarkan biaya ekstra diluar anggaran sebelumnya.

Pada bab sebelumnya telah dibahas mengenai sistem pemberitahuan dalam menyampaikan informasi. Salah satu sistem pemberitahuan tersebut adalah surat elektronik. Melalui analisis masalah yang telah dijelaskan di atas, maka dapat disimpulkan memilih menggunakan surat elektronik sebagai media sistem pemberitahuan. Alasan pemilihan surat elektronik sebagai media sistem pemberitahuan adalah:

1. Hampir semua pengguna Internet pasti mempunyai sebuah akun surat elektronik yang biasa digunakan. 
Berdasarkan riset yang dilakukan oleh the radicati group (radicati.com).

2. Dengan sistem pemberitahuan surat elektronik, pengguna Internet yang mencari produk tidak harus terkoneksi ke Internet setiap saat. Karena biasanya pengguna Internet memiliki smartphone untuk pemenuhan kebutuhannya sehari-hari. Dalam smartphone memiliki layanan push e-mail yaitu sebuah sistem surat elektronik yang memiliki kemampuan menyala terus dimana setiap surat elektronik yang masuk ke dalam server surat elektronik yang akan diteruskan ke email client (aplikasi email) yang berada di dalam telepon pintar (smartphone). Oleh karena itu setiap adanya informasi pesan pemberitahuan akan dikirimkan langsung ke surat elektronik pengguna (Asosiasi Penyelenggara Jasa Internet Indonesia) apji.or.id.

3. Dengan fungsi pemberitahuan surat elektronik, pengguna Internet yang mencari produk tidak harus mengunjungi banyak situs jual beli.

\subsection{Analisis Sistem}

Analisis sistem adalah sebuah teknik pemecahan masalah yang menguraikan sebuah sistem menjadi bagian-bagian komponen dengan tujuan mempelajari seberapa baik bagian-bagian komponen tersebut bekerja dan mendapatkan pemahaman secara keseluruhan dengan sistem yang akan dibuat.

Dalam menganalisa suatu sistem, terdapat beberapa unsur yang harus dilakukan diantaranya adalah masukan sistem, proses sistem, dan keluaran sistem. Berikut uraian dari masing-masing bagiannya.

1. Masukan sistem

Aplikasi pencarian produk secara otomatis dengan fungsi pemberitahuan surat elektronik menggunakan fungsi cURL yang akan dibuat, membutuhkan suatu informasi tentang produk yang akan dimasukkan ke dalam suatu basis data, kemudian digunakan dalam aplikasi ini berupa, informasi kontak pengguna (akun surat elektronik) yang nantinya akan dikirimkan pesan.

2. Proses sistem

Setelah memasukkan informasi di atas, pengguna akan melakukan beberapa tahapan sebagai proses dari sistem, yaitu sebagai berikut:

1. Melakukan pendaftaran.

2. Melakukan aktivasi akun surat elektronik.

3. Melakukan masuk.

4. Mengisi kolom kriteria produk yang diinginkan pengguna.

5. Mengirimkan pesan pemberitahuan surat elektronik.

3. Keluaran sistem
Setelah melalui tahapan masukkan sistem dan proses sistem, keluaran yang akan dihasilkan oleh aplikasi pencarian produk secara otomatis dengan fungsi pemberitahuan surat elektronik menggunakan fungsi cURL adalah pesan surat elektronik yang diterima pengguna berisikan dimana alamat situs produk yang diinginkan berada.

\subsection{Perancangan Sistem}

Perancangan sistem merupakan suatu kegiatan membuat desain teknis berdasarkan evaluasi yang telah dilakukan pada kegiatan analisis. Dari pemaparan analisis masalah dan analisis sistem di atas, maka dapat terkonsep rancangan seperti apa yang dibutuhkan pengguna nantinya.

Perancangan sistem yang akan dibuat di dalam aplikasi ini meliputi: perancangan proses, perancangan basis data, dan perancangan antarmuka (interface) yang akan dibuat.

\subsection{Perancangan Proses}

Perancangan proses merupakan tahapan awal dari perancangan sistem. Perancangan proses dibuat untuk membantu dalam mempermudah pembuatan aplikasi yang akan dibuat. Sehingga proses dalam pembuatan aplikasi ini berjalan sesuai dengan konsep rancangan yang sudah dibuat sebelumnya.

Dalam pembuatan perancangan proses ini, dilakukan beberapa tahap mulai dari awal hingga proses yang diinginkan tercapai. Pada mulanya terdapat proses dari sistem secara keseluruhan. Lalu dilanjutkan dengan proses pendaftaran, proses aktivasi akun surat elektronik, proses masuk ke aplikasi, dan proses pencarian produk. Lihat Gambar 1 sampai dengan Gambar 5.

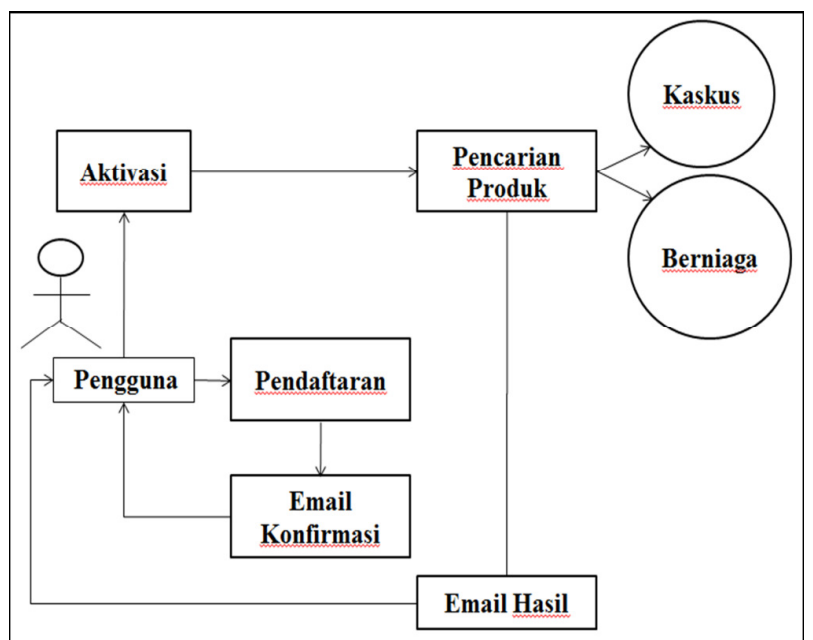

Gambar 1. Diagram Blok Sistem yang akan dibuat. 


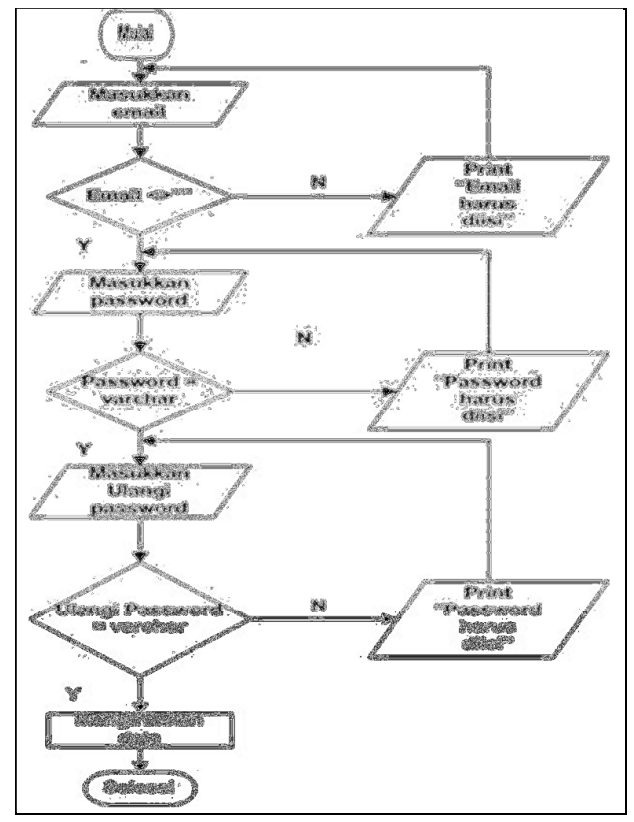

Gambar 2. Diagram Alir Pendaftaran.

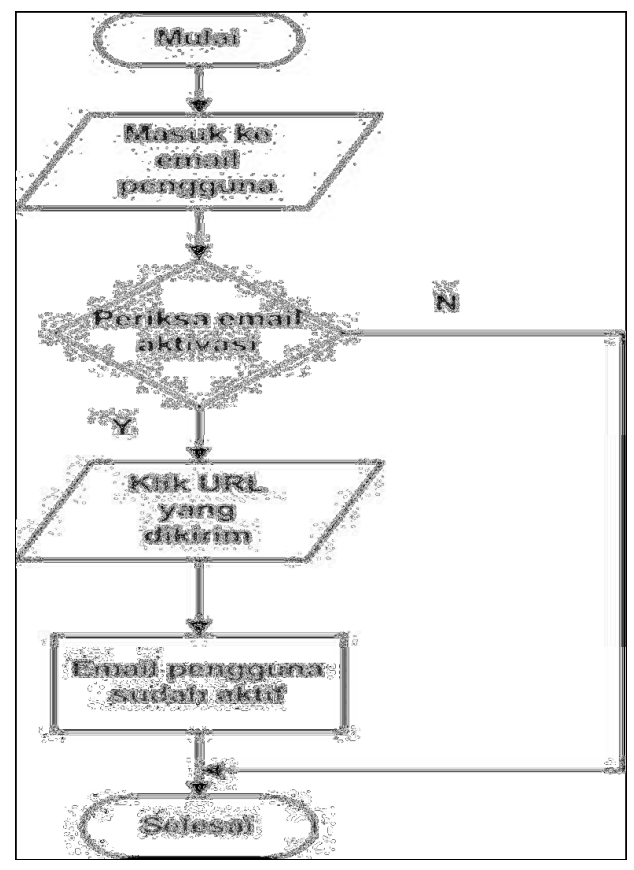

Gambar 3. Diagram Alir Aktivasi.

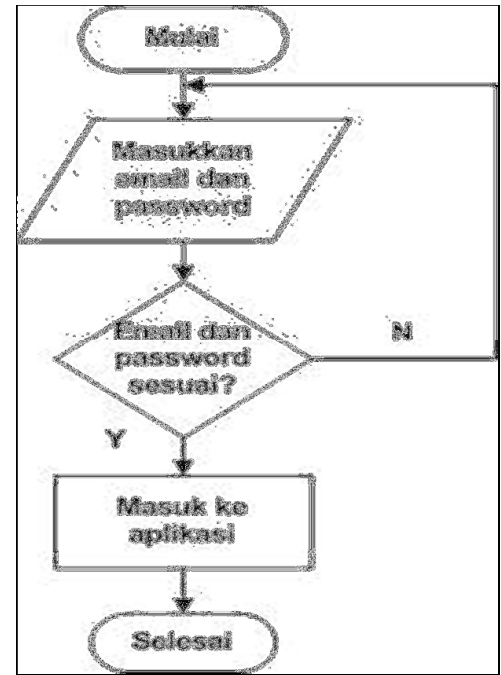

Gambar 4. Diagram Alir Data Masuk.

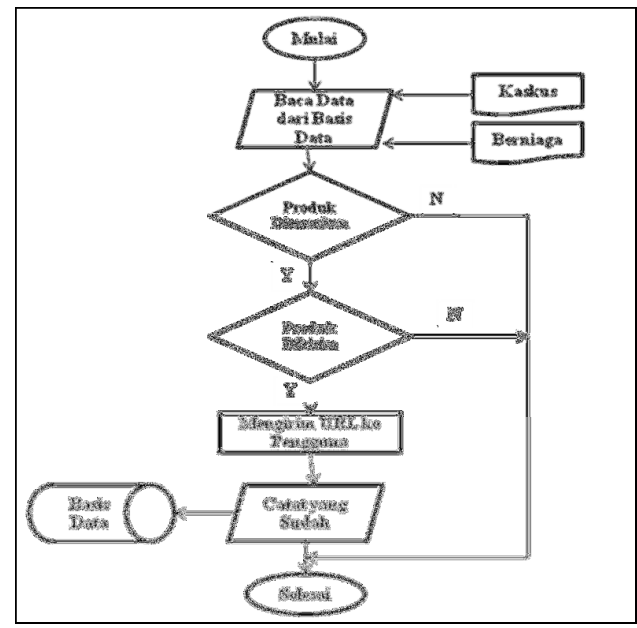

Gambar 5. Diagram Alir Pencarian Produk.

\subsection{Perancangan Basis Data}

Perancangan basis data ini dibuat untuk memperjelas proses dari pembuatan aplikasi ini. Perancangan basis data ini akan menyimpan data-data mulai dari pengguna sampai dengan produk-produk yang dicari oleh pengguna. Untuk mencapai hasil sesuai dengan uraian-uraian yang dipaparkan sebelumnya, maka dari itu dalam perancangan basis data ini dibagi menjadi lima bagian, yaitu mulai dari diagram konteks, diagram alir data, kamus data, diagram keterhubungan entitas, dan struktur rekaman logis. Sehingga pembuatan aplikasi pencarian produk secara otomatis dengan fungsi pemberitahuan surat elektronik ini berjalan sesuai dengan sistem yang teratur. 


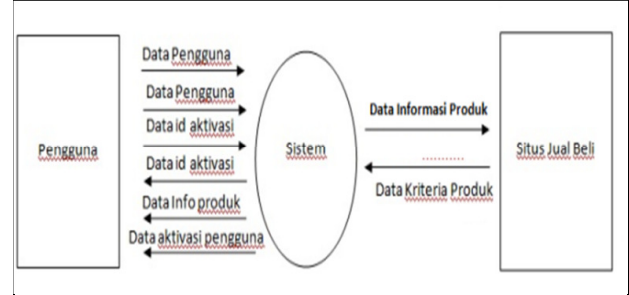

Gambar 6. Model Diagram Konteks.

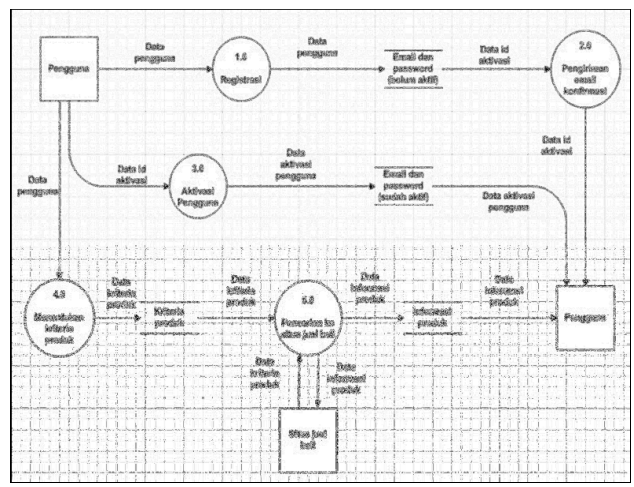

Gambar 7. Diagram Aliran Data.

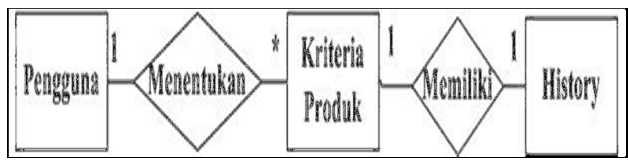

Gambar 8. Model Diagram Hubungan Entitas.

Nama = Pengguna

Deskripsi $=$ Mencari produk

Struktur data $=$ email + pass + aktif

Email $=*$ Akun surat elektronik pengguna terdiri dari 20 digit varchar*

Pass $=*$ Password pengguna terdiri dari 45 digit varchar* Aktif $\quad=*$ Aktivasi akun surat elektronik pengguna 45 digit varchar*

Nama $=$ Produk

Deskripsi $=$ Mencari produk

Struktur data $=$ id_produk $+\mathrm{q}+\mathrm{ps}+\mathrm{pe}+$ lokasi $+\mathrm{w}+$ kondisi_baru + kondisi_bekas + email

Id_produk $=*$ Id produk terdiri dari 5 digit varchar auto increment*

$\mathrm{Q}=$ *Namaproduk terdiri dari 15 digit varchar*

Ps $=$ *Harga awal produk terdiri dari 20 digit number*

$\mathrm{Pe}=*$ Harga akhir produk terdiri dari 20 digit number* Lokasi $=$ *Lokasi produk terdiri dari 20 digit varchar * $\mathrm{W}=*$ Wilayah produk terdiri dari 20 digit varchar*

Kondisi_baru $=*$ Kondisi baru produk terdiri dari 5 digit varchar*

Kondisi_bekas $\quad=*$ Kondisi bekas produk terdiri dari 5 digit varchar *
Nama $=$ History

Deskripsi $=$ Menyimpan url produk

Struktur data $=$ id_produk + toko + ur 1+ email

Id_produk $=*$ Id produk terdiri dari 10 digit int $*$

Toko $\quad=*$ Toko situs jual beli terdiri dari 10 digit varchar*

Url $=*$ Url paling atas tipe text*

Email $=*$ Akun surat elektronik pengguna terdiri dari 40 digit varchar*

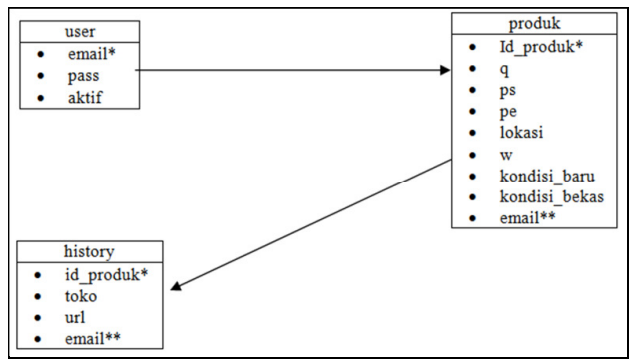

Gambar 9. Struktur Rekaman Logis.

\section{IMPLEMENTASI DAN PENGUJIAN}

\subsection{Implementasi}

Implementasi merupakan penerapan dari perancangan sistem yang telah dibuat pada bab analisis dan perancangan sistem. Pada proses perancangan sistem sebelumnya, membahas mengenai desain teknis berdasarkan evaluasi yang telah dilakukan pada kegiatan analisis masalah dan analisis sistem. Oleh karena itu implementasi ini membahas mengenai potonganpotongan kode, lalu menjelaskannya sesuai dengan potongan kode tersebut.

Implementasi dibagi menjadi tiga bagian yaitu, implementasi proses, implementasi basis data, dan implementasi antarmuka. Implementasi proses adalah tahapan awal dari penerapan perancangan proses yang telah dibuat. Implementasi basis data adalah penerapan dari perancangan basis data. Implementasi antarmuka adalah tahapan terakhir dari implementasi yang menerapkan konsep dari pencangan antarmuka.

\subsection{Implementasi Proses}

Implementasi proses adalah tahapan awal dari implementasi penerapan dari proses yang telah dibuat yaitu perancangan proses. Dalam implementasi proses ini akan dijelaskan penerapan proses berupa gambaran dan potongan kode serta akan dijelaskan setiap bagianbagiannya. Aplikasi ini merupakan aplikasi berbasis web dan menggunakan bahasa pemrograman PHP dengan basis data MySQL yang dapat diakses secara daring.

Untuk itu implementasi proses dibagi menjadi lima bagian proses, sehingga aplikasi ini dapat berjalan sesuai dengan konsep dan perancangan yang telah 
dibuat. Proses-proses yang dimaksud adalah sebagai berikut:

1. Proses pendaftaran pengguna.

2. Proses aktivasi pendaftaran pengguna.

3. Proses masuk ke aplikasi.

4. Proses pencarian data produk.

5. Proses pengiriman data produk.

\section{Implementasi Basis Data}

Implementasi basis data membahas mengenai datadata apa saja yang digunakan pada aplikasi ini. Basis data ini nantinya digunakan untuk menyimpan data-data mulai dari data pengguna sampai data produk.

Basis data dalam aplikasi pencarian produk secara otomatis dengan fungsi pemberitahuan surat elektronik menggunakan fungsi cURL ini dinamai member sedangkan untuk tabelnya terdapat tabel produk dan tabel user. Dalam tabel user ini terdapat tiga kolom yaitu email, pass (password), dan aktif (aktivasi pengguna). Selanjutnya untuk tabel produk terdapat empat kolom yaitu kolom q (nama produk), pe (harga maksimum produk), ps (harga minimum produk), dan lokasi (lokasi produk), kondisi_bekas, dan kondisi_baru. Selanjutnya untuk tabel history terdapat tiga kolom yaitu kolom id_produk (id produk), toko (situs mana produk tersebut), url (url paling atas).

\subsection{Implementasi Penjadwalan}

Implementasi penjadwalan adalah proses untuk menerapkan kerja sistem, melalui proses yang harus berjalan, kapan dan jangka waktu proses sistem akan berjalan, sehingga sistem tidak berjalan dengan manual. Penjadwalan yang digunakan yaitu penjadwalan nonpreemptive, proses yang berjalan tidak dapat disela oleh proses lain hingga proses ini selesai.

Cron job adalah fasilitas yang disediakan oleh hostingan. Cron Job akan menjalankan tugas berupa masukkan ke sistem. Lalu akan menjalankan proses sesuai dengan pengaturan waktu yang disediakan.

Penjadwalan dalam aplikasi ini akan di atur dua kali dalam sehari, pada jam sembilan pagi dan sembilan malam, karena untuk mempermudah pengguna dalam mencari suatu produk. Sintaks yang diisikan berupa alamat dari situs web.

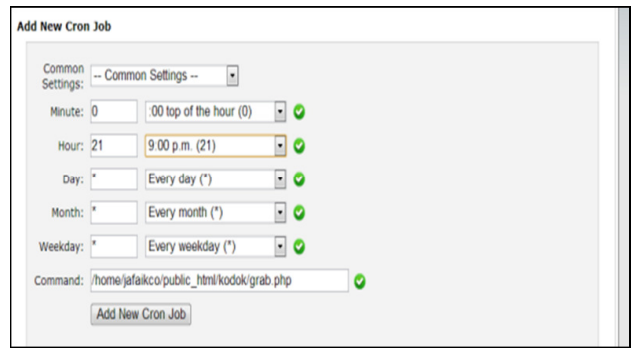

Gambar 10. Implementasi Penjadwalan.

\subsection{Implementasi Antarmuka}

Implementasi antarmuka merupakan penerapan dari perancangan antarmuka pada bab analisis dan perancangan. Implementasi antarmuka merupakan gambaran dari aplikasi ini. Dimana antarmuka ini merupakan faktor penunjang agar aplikasi ini terlihat lebih menarik, sehingga bisa menarik perhatian pengguna untuk selalu menggunakan aplikasi ini bukan hanya dilihat dari segi fungsionalitasnya tetapi juga dari segi tampilannya.

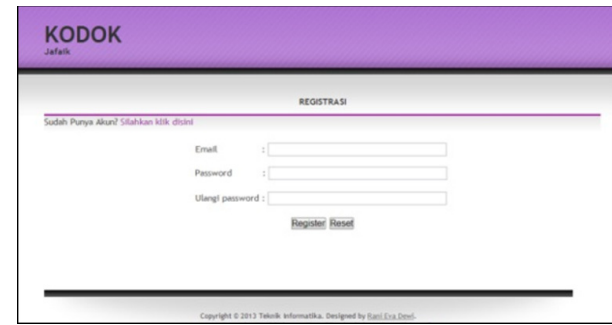

Gambar 11. Tampilan Antarmuka Halaman Registrasi.

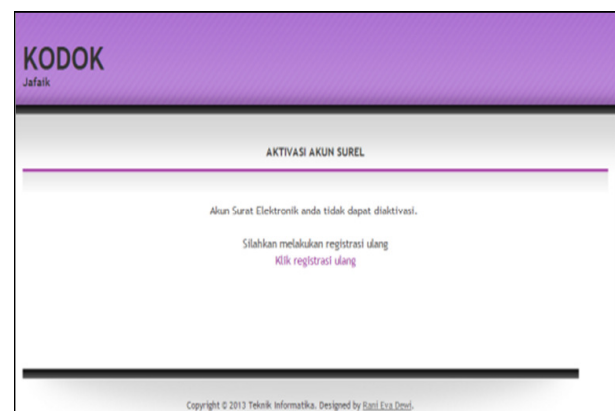

Gambar 12. Tampilan Antarmuka Halaman Aktivasi Surat elektronik

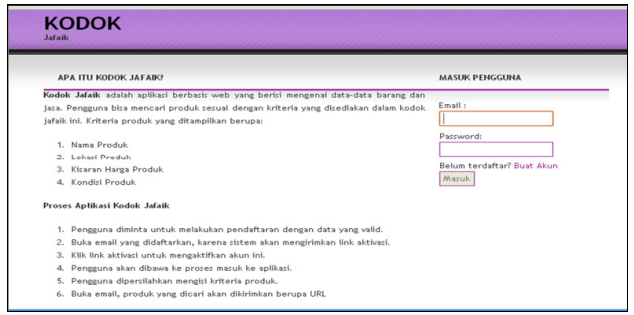

Gambar 13. Tampilan Antarmuka Halaman Masuk.

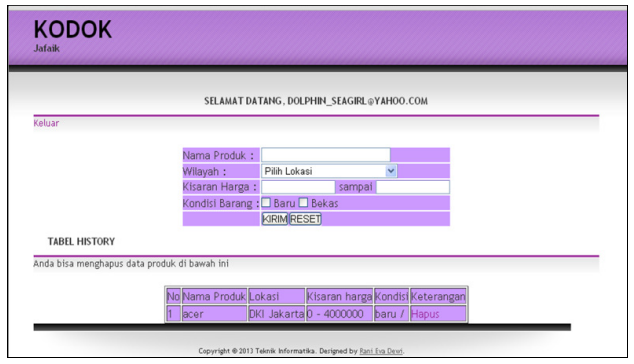

Gambar 14. Tampilan Antarmuka Halaman Pencarian Produk. 


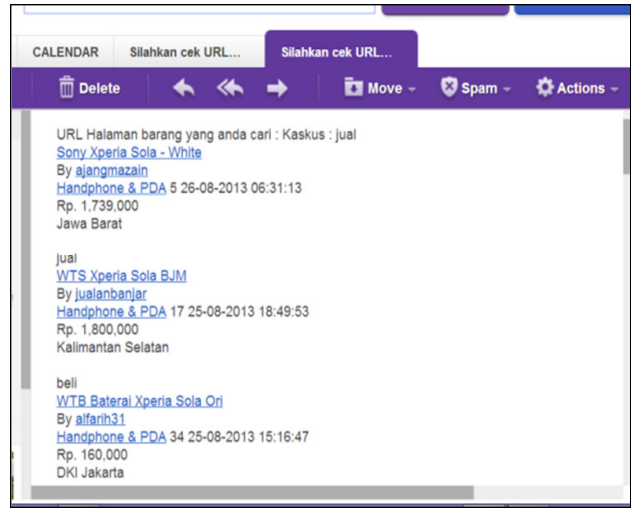

Gambar 15 Tampilan Antarmuka Halaman Produk Ditemukan.

\subsection{Pengujian}

Pengujian fungsionalitas aplikasi merupakan pengujian yang dilakukan dengan menggunakan metode kotak hitam (black box) untuk lebih memfokuskan pada keperluan fungsional dari aplikasi. Dengan menggunakan metode ini, maka validitas fungsi akan diuji, apakah menghasilkan keluaran yang sesuai dengan masukkan yang diharapkan atau tidak.

\subsection{Hasil Pengujian}

Dari hasil pengujian yang dilakukan dapat diperoleh hasil pengujian dari tabel skenario pengujian secara berulang-ulang. Maka diperoleh hasil pengujian tersebut sesuai dengan rumusan rancangan aplikasi program.

Tabel 1 Hasil Pengujian Black Box

\begin{tabular}{|c|c|c|c|c|c|}
\hline No & $\begin{array}{l}\text { Item } \\
\text { yang } \\
\text { diuji }\end{array}$ & Sifat & Cara Pengujian & Hasil yang diharapkan & $\begin{array}{l}\text { Hasil } \\
\text { Pengujian }\end{array}$ \\
\hline \multirow[t]{2}{*}{1} & $\begin{array}{l}\text { Menu } \\
\text { Registrasi }\end{array}$ & Normal & $\begin{array}{l}\text { Memasukkan usemame, email, } \\
\text { password dan confimpassword } \\
\text { pada formmasukpengguna. }\end{array}$ & $\begin{array}{l}\text { Akan muncul teks registrasi } \\
\text { penda ftaran berhasil }\end{array}$ & Sesuai \\
\hline & & \begin{tabular}{l|} 
Tidak \\
Normal
\end{tabular} & $\begin{array}{l}\text { Kosong semua, email kosong atau } \\
\text { email yang sama dengan email } \\
\text { yanglain, password dan confim } \\
\text { password kosong atau password } \\
\text { dan confimpassword berbeda }\end{array}$ & $\begin{array}{l}\text { Akan muncul teks, email } \\
\text { anda sudah digunakan atau } \\
\text { password dankonfimasi } \\
\text { password harus sama }\end{array}$ & Spsuai \\
\hline \multirow[t]{2}{*}{2} & \multirow[t]{2}{*}{$\begin{array}{l}\text { Halaman } \\
\text { aktivasi }\end{array}$} & Normal & Melakukanproses registrasi & $\begin{array}{l}\text { Pengguna bisa masukke } \\
\text { aplikasi }\end{array}$ & Sesuai \\
\hline & & \begin{tabular}{l|} 
Tidak \\
Nomal
\end{tabular} & $\begin{array}{l}\text { Pengguna tidakmengisi halaman } \\
\text { registrasi denganbenar }\end{array}$ & $\begin{array}{l}\text { Pada halamanmasuk tertera } \\
\text { teks anda belum melakukan } \\
\text { aktivasi email }\end{array}$ & Sesuai \\
\hline \multirow[t]{2}{*}{3} & \multirow{2}{*}{$\begin{array}{l}\text { Menu } \\
\text { Masuk } \\
\text { Pengguna }\end{array}$} & Normal & $\begin{array}{l}\text { Memasukkan email dan password } \\
\text { yangbenar }\end{array}$ & Masuk ke halaman home & Sesuai \\
\hline & & $\begin{array}{l}\text { Tidak } \\
\text { Normal }\end{array}$ & $\begin{array}{l}\text { Memasukkan usemame dan } \\
\text { password pada tidak benar }\end{array}$ & $\begin{array}{l}\text { Aplikasi akanmemberikan } \\
\text { pesan"email ataupassword } \\
\text { salah" }\end{array}$ & Sesuai \\
\hline \multirow[t]{2}{*}{4} & \multirow[t]{2}{*}{$\begin{array}{l}\text { Halaman } \\
\text { pencanan } \\
\text { produk }\end{array}$} & Nomal & $\begin{array}{l}\text { Memasukkannama produk, harga } \\
\text { minimum, harga maksimum, dan } \\
\text { lokasi produk pada formpencarian } \\
\text { produk. }\end{array}$ & Menampilkan dataproduk & Sesuai \\
\hline & & $\begin{array}{l}\text { Tidak } \\
\text { Normal }\end{array}$ & $\begin{array}{l}\text { Kosong semua, Memasukkan data } \\
\text { yang salah }\end{array}$ & $\begin{array}{l}\text { Sistem akanmengembalikan } \\
\text { pengguna ke halaman } \\
\text { pencarian produk. }\end{array}$ & Sesuai \\
\hline \multirow[t]{2}{*}{5} & $\begin{array}{l}\text { Halaman } \\
\text { Aplikasi }\end{array}$ & Nomal & $\begin{array}{l}\text { Pencarian data produk dibasis data } \\
\text { situs }\end{array}$ & $\begin{array}{l}\text { Mengirim data produk ke } \\
\text { akun surat elektronik } \\
\text { pengguna }\end{array}$ & Sesuai \\
\hline & & \begin{tabular}{l|l|} 
Tidak \\
Normal \\
\end{tabular} & Pencarian data produk dihentikan & $\begin{array}{l}\text { Sistem akan mengemb alikan } \\
\text { ke halaman aplikasi }\end{array}$ & Sesuai \\
\hline \multirow[t]{2}{*}{6} & $\begin{array}{l}\text { Menu } \\
\text { keluar }\end{array}$ & Nomal & Melakukanklik pada menukeluar. & $\begin{array}{l}\text { Menampilkan halaman } \\
\text { masuk (login) ke aplikasi }\end{array}$ & Sesuai \\
\hline & & \begin{tabular}{l|l|} 
Tidak \\
Normal \\
\end{tabular} & Melakukanklik pada menukeluar. & Tetap pada halamanitu & Sesuai \\
\hline
\end{tabular}

\subsection{Analisis Hasil Pengujian}

Dari hasil pengujian di atas di dapatkan analisis hasil pengujian adalah:

1. Proses registrasi berjalan dengan baik sehingga dapat memberi peringatan pada setiap prosesnya, jika semua kolom registrasi tidak diisi, jika ada data yang tidak valid, dalam artian akun surat elektronik yang berbeda, agar tidak ada data yang sama, jika password dan ulangi password berbeda.

2. Proses aktivasi berjalan dengan baik, sehingga akun surat elektronik yang telah didaftarkan bisa melakukan proses aktivasi dengan cara membuka akun surat elektronik pengguna lalu mengklik URL yang dikirmkan oleh aplikasi.

3. Proses masuk ke aplikasi berjalan dengan baik sehingga hanya akun surat elektronik yang terdaftar saja yang bisa mengakses masuk ke aplikasi ini. Lalu terdapat peringatan disetiap kolomnya.

4. Proses pencarian data produk dapat berjalan dengan baik, sehingga pengguna dapat melakukan akses terhadap aplikasi ini dan bisa mendapatkan produk sesuai dengan permintaan pengguna berdasarkan nama produk, lokasi produk, harga produk, dan kondisi produk.

5. Proses pengiriman data produk berjalan dengan baik, data yang diminta pengguna bisa terkirim ke akun surat elektronik pengguna. Data yang dikirimkan berupa URL, harga produk, wilayah produk, dan siapa pengirimnya, jika URL ini diklik akan terkoneksi langsung ke tempat produk tersebut berada.

6. Proses keluar dari aplikasi berjalan dengan baik, saat diklik tombol keluar, maka sistem akan membawa pengguna ke halaman awal. Jika tidak berhasil, sistem tetap halaman tersebut.

\section{KESIMPULAN DAN SARAN}

\subsection{Kesimpulan}

Berdasarkan tahapan analisis, perancangan sistem implementasi dan pengujian yang telah dilakukan oleh penulis terhadap aplikasi pencarian produk secara otomatis dengan fungsi pemberitahuan surat elektronik menggunakan fungsi cURL, maka penulis mengambil kesimpulan sebagai berikut:

1. Dengan adanya aplikasi pencarian produk secara otomatis dengan fungsi pemberitahuan surat elektronik menggunakan fungsi cURL pengguna dapat mencari berbagai macam produk yang dicari tanpa membuka banyak situs jual beli. Namun penggunaan cURL tidak dapat dilakukan berkalikali oleh server dalam sehari karena akan membebani kinerja server hosting. 
2. Pencarian produk dilakukan dengan mengisikan kriteria produk yang ingin dicari, kemudian url dari hasil pencarian tersebut dikirim melalui akun surat elektronik secara otomatis oleh aplikasi. Namun aplikasi ini belum memiliki menu kategori barang, sehingga pencarian produk belum terlalu detail.

3. Curl digunakan untuk mengambil data dari halaman HTML web lain dengan mengambil beberapa elemen dari suatu web yang kemudian ditampilkan pada halaman aplikasi. Namun jika web lain mengubah struktur maka harus mengubah skrip yang sudah ada pada aplikasi ini.

\subsection{Saran}

Aplikasi yang telah dibuat oleh penulis belum bisa disebut dengan kata sempurna, karena masih terdapat banyak kekurangan. Adapun saran-saran yang diberikan oleh penulis mengenai terhadap aplikasi pencarian produk secara otomatis dengan fungsi pemberitahuan surat elektronik menggunakan fungsi cURL ini agar di masa yang akan datang dapat disempurnakan dan dikembangkan lebih lanjut. Oleh karena itu, saran-saran yang diberikan antara lain sebagai berikut:

1. Dapat dikembangkan penambahan situs jual beli lainnya, agar dalam proses pencarian produk bisa lebih banyak referensi, sehingga pengguna pun bisa lebih cepat dan banyak pilihan dalam mencari produk yang diinginkan.

2. Dapat dikembangkan penambahan kriteria kategori produk, agar pengguna bisa mencari produk dengan berbagai macam kategori.

3. Dapat dikembangkan penambahan gambar produk di halaman aplikasi setelah pengguna mengisi kolom kriteria produk

\section{DAFTAR PUSTAKA}

[1] Keller, Kotler. 2012. Marketing Management. Jakarta: Pearson.

[2] Barkatullah dan Halim, Abdul. 2005. Bisness eCommerce: Studi Sistem Keamanan dan Hukum di Indonesia. Jakarta: Pustaka Pelajar.

[3] Sarwono, Jonathan dan Martadiredja, Tutty. 2008. Teori E-Commerce Kunci Sukses Perdagangan di Internet. Yogyakarta: Gava Media.

[4] Hirin, A M dan Virgi. 2011. Cepat Mahir Pemrograman Web dengan PHP dan MySQL. Jakarta: Prestasi Pustakaraya.

[5] Pressman, Roger S. 2009. Software Engineering: A Practitioner's Approach. Edisi VI. New York:

[6] Cameron, Jamie. 2004. Managing Linux System With Webmin. New York: Pearson.

[7] Fathansyah. 1999. Basis Data. Bandung: CV Informatika.

[8] Greant, Zak dkk. 2002. PHP Functions Essentials Reference. USA: New Riders.

[9] Kustiyaningsih dan Anamisa. 2011. Pemrograman Basis Data Berbasis Web Menggunakan PHP dan MYSQL. Jakarta: Graha Ilmu.

[10] Cullen, Kevin F. 2002. PHP: Anopen source solution for Web Programming and dynamic content. Information Technology and Libraries; 21.3 116-120. Available: http://search.proquest.com/business/docview/21583 2480/135AF4F3DBC1EFB36A0/5? (Diakses 30 april 2013).

[11] http://id.wikipedia.org/wiki/HTML. (Diakses 28 agustus 2013). 